\title{
THE EFFECT OF CAPITAL STRUCTURE AND LIQUIDITY ON FIRM VALUE MEDIATED BY PROFITABILITY
}

\author{
Dian Cahyo Putro \\ Asep Risman \\ University "Universitas Mercu Buana”, Jakarta, Indonesia
}

The purpose of this study is to examine and prove the effect of capital structure and liquidity on firm value as mediated by profitability. The data used in this study are financial reports and annual reports of infrastructure companies (2014-2018), the sample size is nine companies. The analysis technique used is panel data regression (pooled data), with descriptive statistical analysis, stationarity test, regression model selection, classical assumption test, and hypothesis testing in model suitability test $(R 2 m)$, individual parameter significance test (t-test), and sobel test done in the Eviews 10. The results of this study indicate that capital structure and liquidity have no effect on firm value. Profitability was found to be unable to mediate the effect of capital structure on firm value, but was able to mediate the effect of liquidity on firm value.

Keywords: capital structure; liquidity; profitability; firm value

\section{Introduction}

Infrastructure covers basic physical needs organized in a structural system that is needed to guarantee the economy of the public and private sectors with the provision of services and facilities necessary for the economy to function properly. Infrastructure plays an important role in increasing economic growth. When the state of infrastructure in a country is

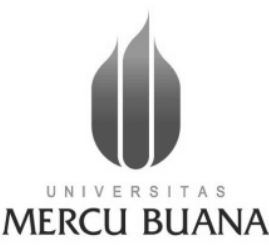

MERCU BUANA

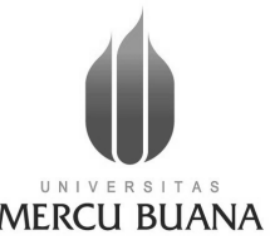

\section{Dian Cahyo Putro}

Researcher, Faculty of Economy and Business, University "Universitas Mercu Buna", Jakarta Indonesia

Research interests: financial stability, corporative finance, international and national business development

Email: cahyodian27@gmail.com

\section{Asep Risman}

Lecturer of University “Universitas Mercu Buna”, Jakarta Indonesia.

Research interests: corporative finance, corporative management, international and national business development

E-mail: asep.risman@mercubuana.ac.id 
weak, it means that the country's economy is operating in a very inefficient manner. If the country's economy does not run efficiently, it will cause very high logistics costs, resulting in the state when companies and businesses lack competitiveness (due to high business costs).

Indonesian government is aware of the importance of improving the state of infrastructure so that the investment and business climate becomes more attractive.

Currently, Indonesian government is carrying out a lot of infrastructure development projects such as toll roads construction, power plants construction projects, reservoirs/dams construction and so on. The budget of Indonesian infrastructure sector is increasing with every new year.

These improving conditions have their impact on competition among the construction companies that would like to get these projects. One of the problems that must be faced by construction companies is the capital that will run the project if it is chosen as the winner. One way that companies can take to meet these fund needs is by selling long-term financial instruments, both stocks and bonds, at the capital market.

The condition of a stock that is in the capital market will affect the interest of investors. The investors' assessment of a stock is an indicator measuring the success of company management, where market strength at the stock exchange is measured through sale and purchase transactions of company's shares at the capital market. Investors will also see the price of a company's shares and decide about investing in it. Finally, share price is an indicator to measure the welfare of shareholders.

Stock price can also describe the value of a company. If the stock price of a company rises, this indicates that company's performance is good. In other words, profits obtained from its operational activities are getting bigger, resulting in the demand for the number of shares which results in an increase in stock prices.

The higher the stock price, the higher the value of the company.

Likewise, the lower the stock price of a company, then the company should get concerned about its poor performance. One of the things that affect investors in their decision-making about investing their shares in a company is by looking at the stock returns that a company can get. Return is the most important measure for investment decisions. Investment is essentially a postponement of current consumption with the aim of obtaining a rate of return that will be received in the future.

Investors can only estimate what the expected return will be and how far it is likely that the actual results will deviate from the expected results.

The results of the research conducted by Lubis et al. (2017) and also by Dhani and Utama (2017) both show that profitability and liquidity have positive effects on firm value. On the other hand, they both also show that capital structure does not affect firm value.

Another case is the research conducted by Hamidy, Wiksuana and Artini (2015). It shows that capital structure has a positive effect on firm value, and also a positive effect on profitability. Meanwhile, profitability has a positive effect on firm value and is also able to mediate the effect of capital structure on the value of a company.

This study aims to determine the effect of capital structure and liquidity, direct or indirect one, on firm value in the construction sector, while profitability serves as a mediation variable. 


\section{THE EFFECT OF CAPITAL STRUCTURE}

\section{Literature Review}

\section{Signaling Theory}

Signaling theory emphasizes that companies are required to disclose information to external parties to minimize information asymmetry and reduce uncertainty about the company's future prospects (Zhang et al., 2017). According to Luthfiah and Suherman (2018), the signaling theory emphasizes that the information published by a company has an important role for investors outside this company. Signaling theory can be also interpreted as an effect arising from the announcement of financial statements whereas these effects can be used as threats and opportunities by other market players while making their investment decisions (Andhov et al., 2019).

Using the signaling theory, companies can increase their value through reporting as the latter is sending signals, usually annually. Information held by management regarding company's internal financial performance reports and information concerning the external market serves to assist management in making decisions that can increase company's value. Company management must wisely determine the information that would simplify decisionmaking both internally and for investors, so that both types of decisions taken will have positive impacts on company's value (Zolochevskaya et al., 2018).

\section{Firm's Value}

Firm value is the present value of expected cash flows and discounted returns that reflect both the risk and the funding used. Meanwhile, company value is the total market value of its debt and shares. For companies that are listed at capital markets, company value is reflected in the market price of its shares (Aprilia, 2018).

In financial management literature, increasing of firm value can be carried out through the functions of financial management, while financial decisions will impact or influence other financial decisions and have implications for firm value. Such financial decisions concern investments and capital structure.

\section{Capital Structure}

Capital structure is part of the financial structure which can be interpreted as the reflection of the balance between long-term debt and equity. One of the most important decisions as to financial functions concern company's ability to meet the needs in funds that will be later used for both operational activities and for expansion. Fulfillment of such funding needs can be obtained both internally and externally.

The forms of internal financing include retained earnings and depreciation. External sources of funding can be divided into debt financing and equity financing. Debt financing can be obtained through loans, while own capital is usually obtained through the issuance of new shares.

Thus, capital structure is defined as a balance or comparison between the amount of long-term debt and equity (Jensen \& Meckling, 1976).

\section{Liquidity}

Liquidity is directly related to the company's ability to meet its financial obligations that must be paid off immediately. In liquidity there are three basic components - density, 
depth and resilience. These components are interrelated as they serve to maintain the level of liquidity and economic stability in a company.

The following is the explanation of these three components. Density - the gap or distance that occurs between the normal price of an item and the agreed price. Depth - the amount or volume of goods sold and purchased at a certain price level. Resilience - the speed of price changes toward efficient prices after a deviation or price instability occurs.

\section{Profitability}

Profitability is the company's ability to earn profits. The greater the level of profit, the better management will be in managing the company. The measure of profitability can be divided into various indicators, such as operating profit, net income, rate of return on investment or assets, and the rate of return on owner's equity. Profitability is one of the basic indicators for assessing the overall condition of a company.

\section{Methodology}

This research study uses path analysis along with the model used by Risman et al. (2017, 2020), according to which:

H1: Capital structure has a direct effect on firm value.

H2: Liquidity has a direct effect on firm value.

H3: Capital structure has an indirect effect on firm value through the mediating variable of profitability.

H4: Liquidity has an indirect effect on firm value through the mediating variable of profitability.

Operationalization of the key variables in this study is presented in Table 1 below.

Table 1 - Operational Variables

(Results of co-authors study)

\begin{tabular}{|l|c|c|}
\hline \multicolumn{1}{|c|}{ Variables } & Proxy & Measurement \\
\hline Capital Structure & DER & $\frac{\text { Total Debt }}{\text { Capital }}$ \\
\hline Liquidity & CR & $\frac{\text { Current Assets }}{\text { Current Debt }}$ \\
\hline Profitability & ROA & $\frac{\text { Eaning After Tax }}{\text { Total Assets }}$ \\
\hline Firm value & Tobin's Q & $Q=\frac{(E M V+D)}{(E B V+D)}$ \\
\hline
\end{tabular}

The entire population of 9 (nine) companies is used as our sample, so this research can be treated as a census research. 


\section{THE EFFECT OF CAPITAL STRUCTURE}

This study has used panel data (pooled data), which is a combination of time series data and cross-section data from nine companies across five years (2014 to 2018).

\section{Results and Discussion}

\section{Stationarity Test}

Table 2 - Unit Root Test Results

(Results of co-authors study)

\begin{tabular}{|ccc|}
\hline \multirow{2}{*}{ Variable } & \multicolumn{2}{c|}{ Level } \\
\cline { 2 - 3 } & $\mathrm{p}$-value & Conclusion \\
\hline Tobins'Q & 0.0000 & Stationary \\
\hline DER & 0.0000 & Stationary \\
\hline CR & 0.0000 & Stationary \\
\hline ROA & 0.0000 & Stationary \\
\hline
\end{tabular}

From the results of the stationary test in Table 2 above, it can be seen that all the variables in this study are stationary.

\section{Multicollinearity Test}

Table 3 - Multicollinearity Test Results of the Regression Equation (Results of co-authors study)

\begin{tabular}{|ccccc|}
\hline & Q & DER & CR & ROA \\
Q & 1.000000 & 0.256914 & -0.173115 & 0.330941 \\
DER & 0.256914 & 1.000000 & -0.601204 & -0.017502 \\
CR & -0.173115 & -0.601204 & 1.000000 & 0.351712 \\
ROA & 0.330941 & -0.017502 & 0.351712 & 1.000000 \\
\hline
\end{tabular}

From Table 3 above, the regression equation for each variable has a multicollinearity value below 0.8 which means that in this study there is no multicollinearity problem in the research variables.

\section{Heteroscedasticity Test}

Table 4 - Heteroscedasticity Test Results of the Regression Equation (Results of co-authors study)

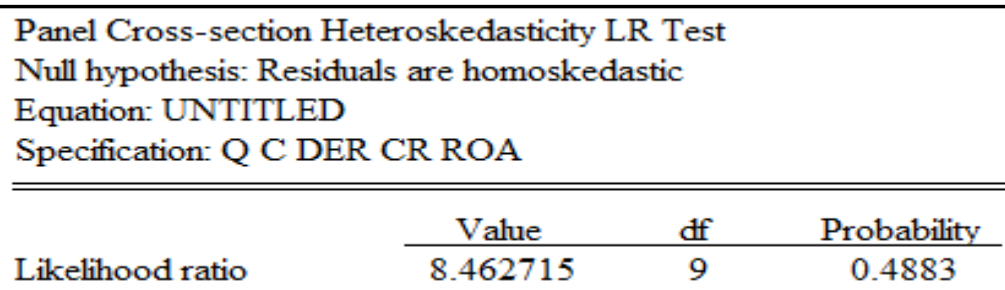


The heteroscedasticity test of the regression, namely the heteroscedasticity LR test method, shows that the prob value is 0.4883 , which is greater than the 0.05 significance level. Thus, it can be concluded that there is no heteroscedasticity in our research model.

\section{Panel Data Regression Model Selection}

Table 5 - The results of the regression model selection test (Results of co-authors study)

\begin{tabular}{|l|c|c|c|}
\hline \multirow{2}{*}{ Testing } & Indicators & Probability & \multirow{2}{*}{ Accepted Model } \\
\hline \multirow{2}{*}{ Chow test } & Cross-section F & 0.5842 & \multirow{2}{*}{ Common Effect } \\
\cline { 2 - 3 } & Cross-section Chi-square & 0.4111 & Random Effect \\
\hline Hausman test & Cross-section random & 0.4995 & Common Effect \\
\hline LM test & Cross-section One-sided & 0.4806 & \multicolumn{2}{|c}{} \\
\hline
\end{tabular}

According to the p-value, a suitable regression model has the common effect.

\section{Goodness of Fit Model}

Table 9 - R-Square (R2)

(Results of co-authors study)

\begin{tabular}{|c|c|c|}
\hline Construct & Regression Equation & R2 Value \\
\hline $\mathrm{R} 1$ & Firm's Value $=\alpha+\beta 1 \mathrm{DER}+\beta 2 \mathrm{CR}+\beta 3 \mathrm{ROA}+\mathrm{e}$ & 0,212509 \\
\hline $\mathrm{R} 2$ & $\mathrm{ROA}=\alpha+\beta 1 \mathrm{DER}+\beta 2 \mathrm{CR}+\mathrm{e}$ & 0,182610 \\
\hline
\end{tabular}

From Table 9 above, the following results are obtained:

$$
\mathrm{Q} 2=1-((1-0,212509) \times(1-0,182610))=0,356312
$$

This figure shows the good influence of the two independent variables and the mediating variable that can affect firm value.

\section{Hypotheses Testing}

Table 10 - Hypotheses Testing Results

(Results of co-authors study)

\begin{tabular}{|c|c|c|c|}
\hline Hs & Variables Relationship & Prob. & Significant/ Not Significant \\
\hline H.1 & DER $\rightarrow$ Firm Value & 0.5399 & not significant \\
\hline H.2 & CR $\rightarrow$ Firm Value & 0.1910 & not significant \\
\hline H.3 & DER $\rightarrow$ ROA $\rightarrow$ Firm Value & 0.1412 & not significant \\
\hline H.4 & CR $\rightarrow$ ROA $\rightarrow$ Firm Value & 0.0405 & significant \\
\hline
\end{tabular}




\section{THE EFFECT OF CAPITAL STRUCTURE}

\section{Effect of Capital Structure on Firm Value}

Based on the results of testing our hypotheses, the capital structure has no effect on firm value. This shows that the use of high debt will cause higher interest expenses. This also results in reduced company assets to cover these expenses.

The results of this study support the previous empirical findings of Lubis et al. (2017), Lestari (2017), Dhani and Utama (2017) who found that capital structure has no effect on firm value.

\section{The Effect of Liquidity on Firm Value}

Based on the results of testing the hypotheses, liquidity has no effect on firm value. In other words, investor does not often pay attention to firm liquidity, primarily because this ratio only shows the company's ability to pay short-term obligations with the company's current assets.

The results of this study support the previous empirical findings of Lubis et al. (2017) and Dhani and Utama (2017).

\section{The Effect of Capital Structure on Firm Value Mediated by Profitability}

This study has found that profitability was not able to mediate the effect of capital structure on firm value. This shows that the addition of the profitability variable or the ability to earn profits does not affect leverage in increasing firm value.

The results of this study support the previous empirical findings of Aprilia et al. (2018), who also have found that profitability was not able to mediate the effect of leverage on firm value.

\section{The Effect of Liquidity on Firm Value is Mediated by Profitability}

This study has found that profitability was able to mediate the effect of liquidity on firm value. This shows that the addition of the profitability variable or the ability to earn profits can affect liquidity in increasing firm value. Profits obtained by a company through the sale of assets that it owns, can add value to this company's liquidity.

The results of this study support the previous empirical findings of Aprilia et al. (2018) who also found that profitability was able to mediate the effect of capital structure on firm value.

\section{Conclusion and Suggestions}

The following conclusions can be drawn from the research results above:

1. Capital Structure has no effect on Firm Value.

2. Liquidity has no effect on Firm Value.

3. There is no influence of Capital Structure on Company Value which is mediated by Profitability.

4. Profitability can mediate the effect of Liquidity on Firm Value.

Our suggestions that are stemming from the results of this study are as follows:

1. Companies should always consider the value of their profitability because it is proven to be able to mediate the relationship between liquidity and firm value. Profits 
obtained by the company through the sale of owned assets can add value to this company's liquidity. This ultimately becomes of interest for both investors and potential investors of the company. The more investors invest their capital, the more the share price will rise. And when the company's stock price rises, then the company's value also increases. The higher the company value, the more valuable the company overall is.

2. For investors and potential investors, profitability can be used as an indicator to determine the value of the company. This is mainly because profitability is able to mediate liquidity against firm value. High profitability can increase the company's liquidity value. This shows that the company can guarantee its short-term debt with the profits earned. Companies with a high level of liquidity will increase the probability of future dividend distribution in the form of cash.

\section{References:}

1. Andhov, A., Brocková, K. \& Šimalová, K. (2019). Slovakia. In Investment Arbitration in Central and Eastern Europe : Law and Practice. Cheltenham; Northampton: Edward Elgar Publishing.

2. Aprilia, R. et al. (2018). Current Ratio, Total Asset Turnover, and Debt to Equity Ratio. Komunikasi Ilmiah Akuntansidan Perpajakan, 11(3), 329-358.

3. Dhani, I. P. \& dan Utama, A. A. (2017). Pengaruh Pertumbuhan Perusahaan, Struktur Modal, Dan Profitabilitas Terhadap Nilai Perusahaan. Jurnal Riset Akuntansi dan Bisnis Airlangga, 2(1), 135-148.

4. Hamidy, R. R., Wiksuana, I. G. B. \& dan Artini, L. G. S. (2015). Pengaruh Struktur Modal Terhadap Nilai Perusahaan Dengan Profitabilitas Sebagai Variabel Intervening Pada Perusahaan Properti Dan Real Estate Di Bursa Efek Indonesia. E-Jurnal Ekonomi Dan Bisnis Universitas Udayana, 4(10), 665-682.

5. Jensen, M.C. \& Meckling, W. H. (1976). Theory of The Firm: Managerial Behavior, Agency Cost, and Ownership Structure. Journal of Financial Economics, 3 (4), 305-360.

6. Lubis, I. L., Sinaga, B. M. \& dan Sasongko, H. (2017). Pengaruh Profitabilitas, Struktur Modal, Dan Likuiditas Terhadap Nilai Perusahaan. Jurnal Aplikasi Bisnis dan Manajemen, 3(3), 458465.

7. Luthfiah, A. A. \& Suherman, S. (2018). The Study On Manufacturing Companies Listed In Indonesia Stock Exchange In The Period Of 2012-2016. Journal of Business and Behavioural Entrepreneurship, 2(1), 18-27.

8. Risman, A. \& Salim, U. \& Sumiati, Sumiati \& Indrawati, L. (2017). Commodity prices, exchange rates and investment on firm's value mediated by business risk: A case from Indonesian stock exchange. European Research Studies Journal, 20, 511-524.

9. Risman, A. \& Parwoto Sulaeman, A. (2020). The Mediating Role of Firm's Performance on The Relationship between Free Cash Flow and Capital Structure. Psychology and Education Journal, 58 (1), 1209-1216.

10. Zhang, L. Grešš, M. \& Brocková, K. (2017). Current and potential Chinese foreign direct investment in the Slovak Republic. Baltic Journal of European Studies, 7(1), 84-96 


\section{THE EFFECT OF CAPITAL STRUCTURE}

11. Zolochevskaya, E.Yu., Cherkasova, T.P., Mishurina, O.V. \& Sivakova, Ya. E. (2018). Institutional Design In The System Of State Policy Measures For Stimulating Economic Growth In Russia In The Context Of Geopolitical Challenges. CBU International Conference Proceedings, 510-515.

Paper submitted

Paper accepted for publishing

Paper published online
21 November 2020

09 January 2021

31 March 2021 